\title{
STONE AGE DWELLINGS, SITES AND ENVIRONMENT IN COASTAL NORTHERN NORWAY: SURVEYS AND DOCUMENTATION OF HOUSE-PIT SITES
}

(C) 2021

\author{
Skandfer M. ${ }^{1}$, Damm Ch. ${ }^{1}$, Gjerde J.M. ${ }^{2}$ \\ ${ }^{1}$ The Arctic University of Norway (Tromso, Kingdom of Norway) \\ ${ }^{2}$ Norwegian Institute for Cultural Heritage Research (Tromso, Kingdom of Norway)
}

\begin{abstract}
The northernmost parts of Europe has a large number of sites with Stone Age house-pits, the majority of which date from c. 5000 BC onwards. Remarkably, the remains of these dwellings are many places still visible on the surface. In northern Norway, such dwellings concentrate in the coastal areas, with a more limited number found on inland sites. In order to use these in analyses of settlement duration, distribution and organization a more uniform and coherent documentation of both individual structures and site characteristics must be ensured. In an ongoing research project on Stone Age Demographics, we have developed and tested different levels of settlement site documentation, scaling from single structures over site topography to reconstruction of past environments. Through substantial surveying in our study region in coastal western Finnmark, northern Norway, we have collected extensive and uniform documentation of dwellings, sites and environment. This systematic documentation allows us to not just discuss dwellings within one specific site, but to consider also regional and supra-regional patterns and variability. This is required if we are to consider both spatial variation and temporal developments in the use and role of pit-houses.

Keywords: Stone Age; dwelling site; house-pit; systematic documentation; seascape; Finnmark; northern Norway.
\end{abstract}

\section{ЖИЛИЩА, ПОСЕЛЕНИЯ И ПРИРОДНЫЕ УСЛОВИЯ КАМЕННОГО ВЕКА В ПРИМОРСКИХ РАЙОНАХ СЕВЕРНОЙ НОРВЕГИИ: ПОИСК И ДОКУМЕНТАЦИЯ ПОСЕЛЕНИЙ С УГЛУБЛЕННЫМИ ЖИЛИЩАМИ}

(C) 2021

\author{
Скандфер М. ${ }^{1}$, Дамм ш. ${ }^{1}$, Йёрде Я.М. ${ }^{2}$ \\ ${ }^{1}$ Арктический университет Норвегии (г. Тромсё, Королевство Норвегия) \\ ${ }^{2}$ Норвежский институт по изучению культурного наследия (2. Тромсё, Королевство Норвегия)
}

Аннотация. В самой северной части Европы выявлено большое количество углубленных жилищ каменного века, большинство из которых датируются начиная с 5 тыс. до н.э. Примечательно, что в большинстве мест следы этих жилищ до сих пор видны на поверхности. В Северной Норвегии они концентрируются на побережье, а во внутренних районах количество жилищ ограниченно. Для изучения длительности их бытования, распространения и организации необходимо создание единообразной и непротиворечивой документации как отдельных объектов на памятниках, так и поселений в целом. В рамках текущего исследовательского проекта по демографии каменного века нами была разработана и протестирована система документации, учитывающая характеристики от уровня отдельных конструкций до топографии поселений и реконструкции природной среды прошлого. В ходе исследований на побережье западного Финнмарка (Северная Норвегия) нами была собрана обширная информация о жилищах, поселениях и природной среде, систематизированная по единому шаблону. Такая документация позволяет нам рассматривать сходства и различия жилищ не только внутри одного определенного поселения, но и на региональном и более высоком уровнях. С ее помощью мы можем рассматривать как пространственное разнообразие в целом, так и кратковременную изменчивость в использовании и роли углубленных жилищ.

Ключевые слова: каменный век; углубленные жилища; систематическая документация; морской пейзаж; Финнмарк; Северная Норвегия.

\section{Introduction}

A large number of sites with Stone Age house-pits are known from northernmost parts of Europe, the large majority dating from c. $5000 \mathrm{BC}$ onwards. Overall numbers of house-pit sites are approximately eight times higher per $\mathrm{km}^{2}$ in coastal Finnmark, northernmost Norway, than in comparable areas of Finland, and approximately 18 times higher than in Norrbotten County in northern Sweden [1]. This clearly indicates that the prehistoric coastlines of Finnmark were extensively settled, and makes the region particularly well-suited for analyses of settlement dynamics. However, although the Stone Age house-pit is a well-established empirical phenomenon in northern Fennoscandia, and despite a long research record on Stone Age house-pits and sites along the Finnmark coast, we lack standardized concepts and methods to describe them. This makes it difficult if not impossible to do meaningful comparisons and suggest patterns and trends in time and space without comprehensive, new, field studies.

The research-project 'Stone Age Demographics' has focused on the western Finnmark region, which provides many dwelling sites as well as a highly varied topography and environment. Over four field seasons, we have developed and tested standardized documentation on different levels, from local environments over site structuration to dwelling characteristics. By visiting a broad specter of different local landscapes, we have increased the number of known Stone Age dwelling sites in the region by $30 \%$. Our overall aim with this paper is to share some results and reflections regarding systematic documentation of dwellings, sites and landscapes, and to en- 
vision how this enables us to identify and compare prehistoric environmental qualities, settlement organization and dwelling variation in time and space.

\section{Documenting local environments}

In order to identify favourable qualities in the local environments and get insight into of the preferences behind settlement locations in the Stone Age, it is important to establish an understanding of the wider geography and topography of an area. Many places of the past landscape differed from the present-day landscape to such a degree that it offered quite other qualities, characteristics that were part of determining settlement site locations. The significant variations in the coastal landscape of Western Finnmark (fig. 1) make it ideal for the study of the importance of environmental characteristics to Stone Age settlement. The general picture is that of a coastal seascape with fjords and sounds in addition to minor inlets and bays. On the outer coast the large island Sørøya, itself displaying fjord systems, is separated from three large islands by a major sound, Sørøysund. Between the islands other sounds funnel into the mouth of the Altafjord. The head of the large Altafjord connects to inland river valleys. The region displays numerous tributary fjords and side branches to the main waterways.

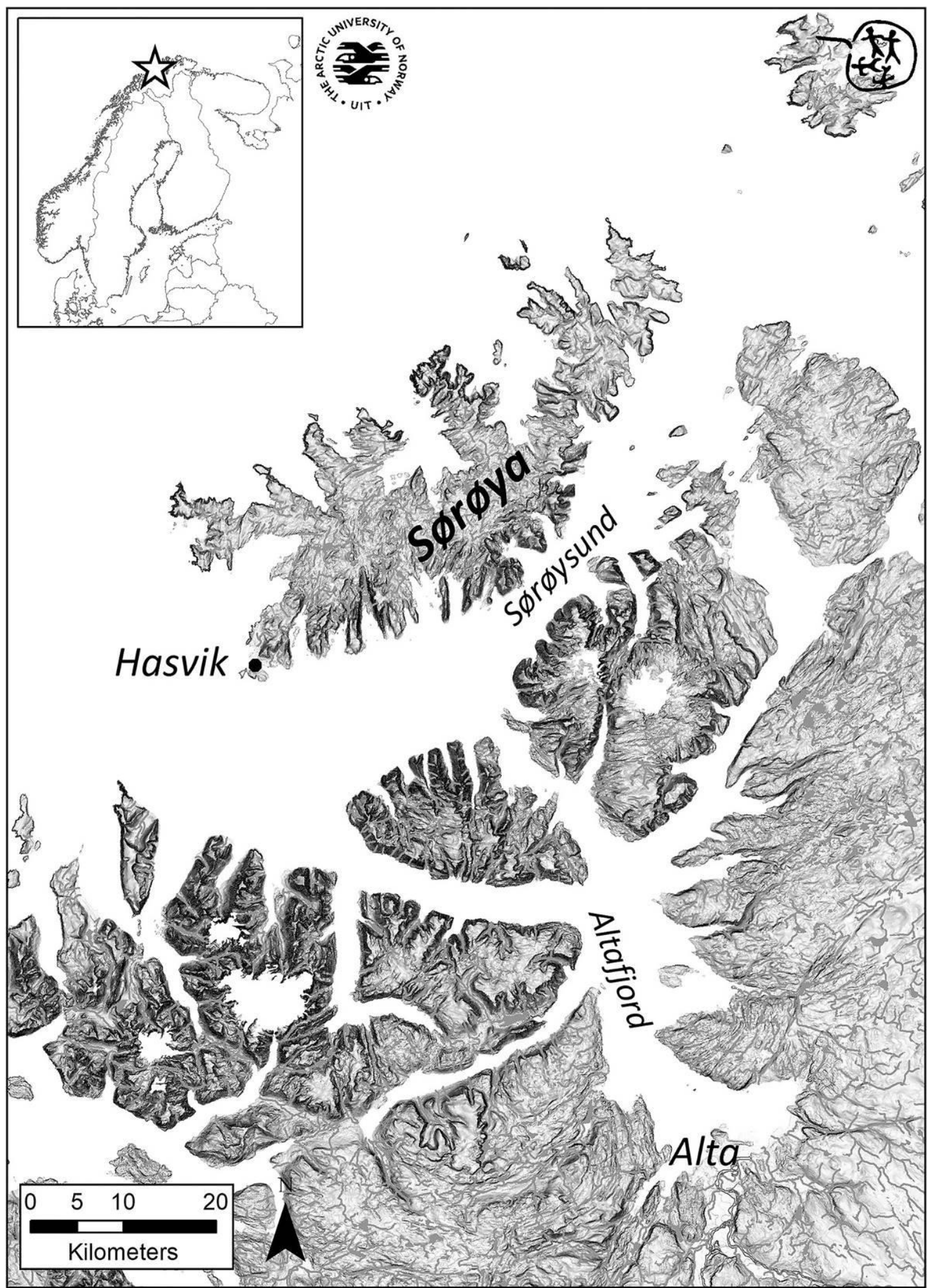

Figure 1 - Western Finnmark, North Norway (map by G. Skogsvold, UiT) 
The landscape varies from steep cliffs and mountains rising straight from the sea, via coastal rock slopes to pebble or sandy beaches, typically situated at the head of fjords and bays (fig. 2). While the steep landscapes dominate, other areas are relatively flat with low-modulated terraces and valleys. The vegetation in the coastal zone is dominated by heather-covered lowlands and birch woodland, but also includes enclaves of dense pine-forests in the inner Altafjord [1]. The large variation in overall and local topography as well as vegetation provides a landscape of mixed qualities within relatively short distances, some of them super-local. This needs to be accounted for when discussing the characteristics of the environment of an area and of a site's locational qualities.

The landscape in western Finnmark, as in the rest of Fennoscandia, has undergone major changes during the Holocene. The most significant is the land uplift, which is apparent in the whole area. The land uplift had greater impact in the inner areas of the Altafjord than in the outer area, e.g. at Sørøya. Simplified, the gradient land uplift means that shorebound settlements dating to c. 5000 $\mathrm{BC}$ at the head of the Altafjord are now situated about 25 metres above the present shoreline while at Sørøya contemporary settlements are found at c. 14 metres. It is vital to be aware of this difference when comparing local environments across the study area, to ensure the use of the same characteristics for comparisons within and between time-frames. To get a relative date for the reconstructed landscape setting, geological land uplift data are applied based on the computer program Sealev98 (http://geo.phys.uit.no/sealev). The land uplift data enables us to make reconstructed landscapes applying GIS software, where reconstructed shorelines are mapped in relation to the landscape setting at different times (fig. 3). In turn, this visualises lost topographical relations such as minor wind-breaking islands outside a settlement site or small bays providing alternative and additional landings to larger bays. These may have been important features although discrete, differing from the present landscape and difficult to discern without this approach.

Initial studies of the archives, maps, aerial photos and LIDAR data (where available) were applied to get an impression of the landscape as such and of the landscape in relation to the sites, and to identify possible patterns in order to predict site locations. The following fieldwork investigations aimed to systematically document multiple characteristics of the local environment for each settlement site. These included local topography (i.e. island, modulation of coastline, bay, peninsula, saddle), terrain shape (i.e. flat, gently sloping, marked terraces, rocky, below steep mountain cliff), access to harbour (number and direction(s) of), type of local seascape (i.e. shallow water, sound, fjord, archipelago, open sea), access to inland (rivers/lakes, valleys, highlands) access to fresh water (distance to and type of), degree of wind/weather exposure or shelter, and view to prominent landscape features.

\section{Documenting sites}

One of the aims for studying Stone Age forager habitation in a wider region is of course to consider settlement organization. We may expect different sites to have served different purposes. The abundancy of Stone Age sites and structures in western Finnmark furthermore provides potential for discussing settlement distributions and densities at both local, regional and supra-regional scale. These research questions require documentation of multiple sites, using similar parameters and methods. In this, we attempt to move beyond simply marking sites on a map. We are interested in the type of site (open air or with dwelling structures), the variation in types of structures (if any), the size (geographical extension and number of dwellings) and the internal organization of each site.

Based on initial search in databases, archives and publications our comprehensive fieldwork partly revisited and re-documented known sites and partly searched for new sites. Ideally, one would want to survey for and record both open air sites and sites with dwelling remains (and other types of sites). Test-pitting is, however, time consuming. The recent large-scale rescue excavations in northernmost Norway, where the topsoil is stripped away from extensive areas, provide insight into how representative house-pits are as dwelling type. The large-scale excavations suggest that for the period 5000$0 \mathrm{BC}$ by far the majority of dwellings are linked to more substantial structures such as house-pits. Still, sites without visible structures or surface finds must be assumed to be underrepresented in the northern Norwegian record. Similarly, modern activity such as farming, modern habitation and infrastructure has destroyed some areas with high potential for Stone Age sites (e.g. around the modern Alta town), while in other parts of our research area increased vegetation due to reduced grazing and warmer climate is making it increasingly hard to survey for sites. These issues must be taken into account when evaluating the distribution of sites.

Georeferencing sites and individual structures through GPS (Global Positioning System) or CPOS (Centimeter POSitioning) at a site for further analysis through GISplatforms (Geographical Information System) is a highly useful approach. The high precision of the satellite-based georeference delivers an accurate map of a site and the spatial distribution of each of the dwellings within it (fig. 4). It also allows us to model the dwellings in relation to past shorelines. An additional tool is photogrammetry, ideally using drones to photograph an entire site from the air. The photos can then be transformed into 3D-models of the site, allowing evaluation of the topography and precise placement of for example house-pits, and even measure their size and depth.

In western Finnmark the size of the sites with housepits varies a great deal. Some have only a few dwellings although sites with just one is unusual, 5-14 dwellings are common, and a small number of sites have 15 or more dwellings, with 66 being the largest number of dwellings documented at one site. At some sites, the dwellings are packed into small and confined areas taking up all available space. At others, large parts may be unexploited with room for many more dwellings. Further, there is only a limited number of other visible structures at the sites, such as pits or possible burial cairns.

It must be emphasized that at most medium and large sites (and perhaps even at the small sites) not all dwellings are contemporary. Based on inventory, radiocarbon dates and height above sea level it is evident that many sites were used and re-visited repeatedly over centuries and even millennia. Some sites, however, were probably used only a few times, and some abandoned after an initial phase, for example due to regressing shorelines. In the topographically highly varied landscape, even small changes in sea level would alter shorelines and change landing facilities dramatically, and in turn make settlement sites less favorable. 


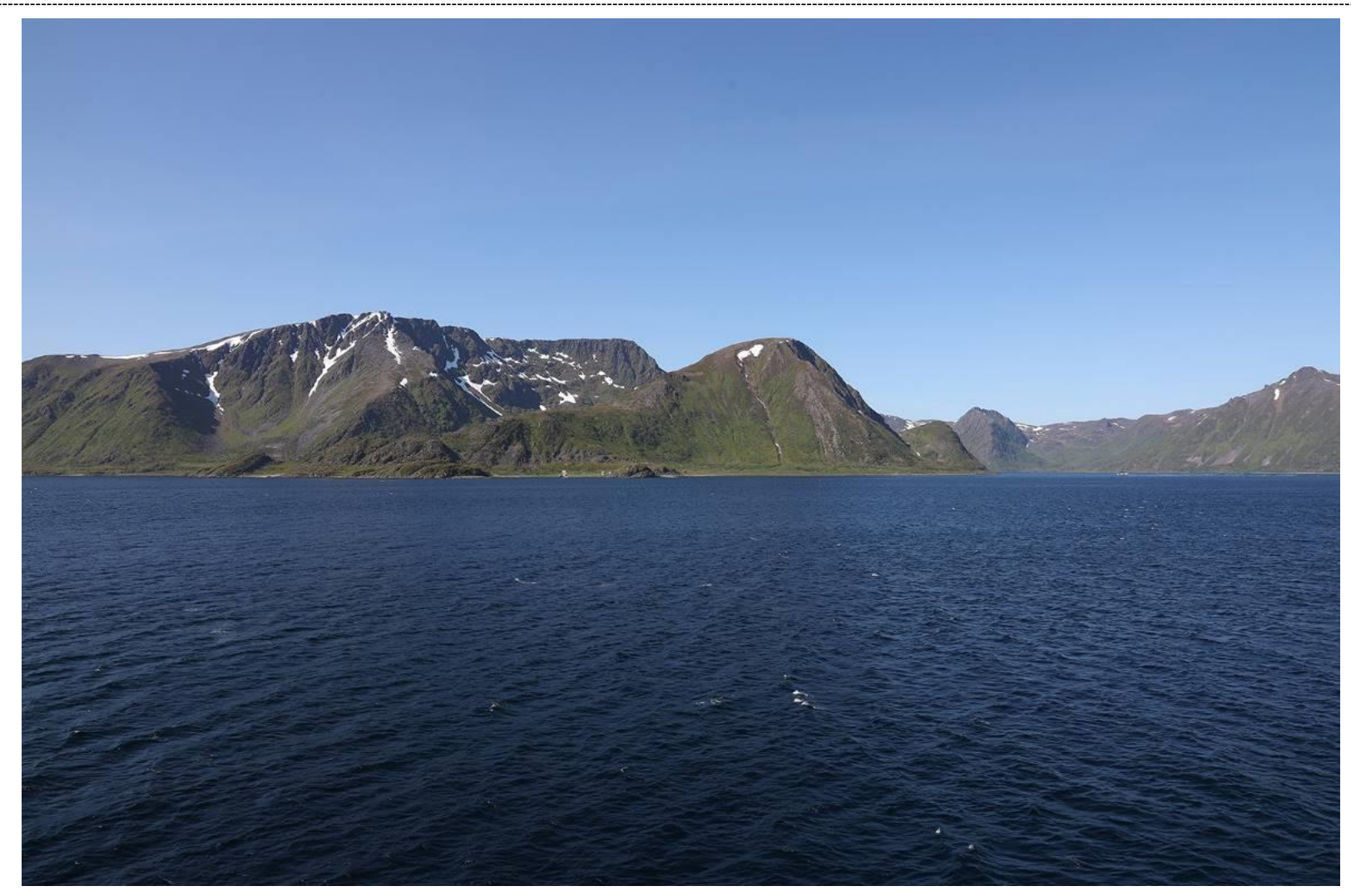

Figure 2 - Photo of the seascape at Sørøya Island towards the Stone Age sites at Vatnhamna and Vatnan (photo by J.M. Gjerde, NIKU)

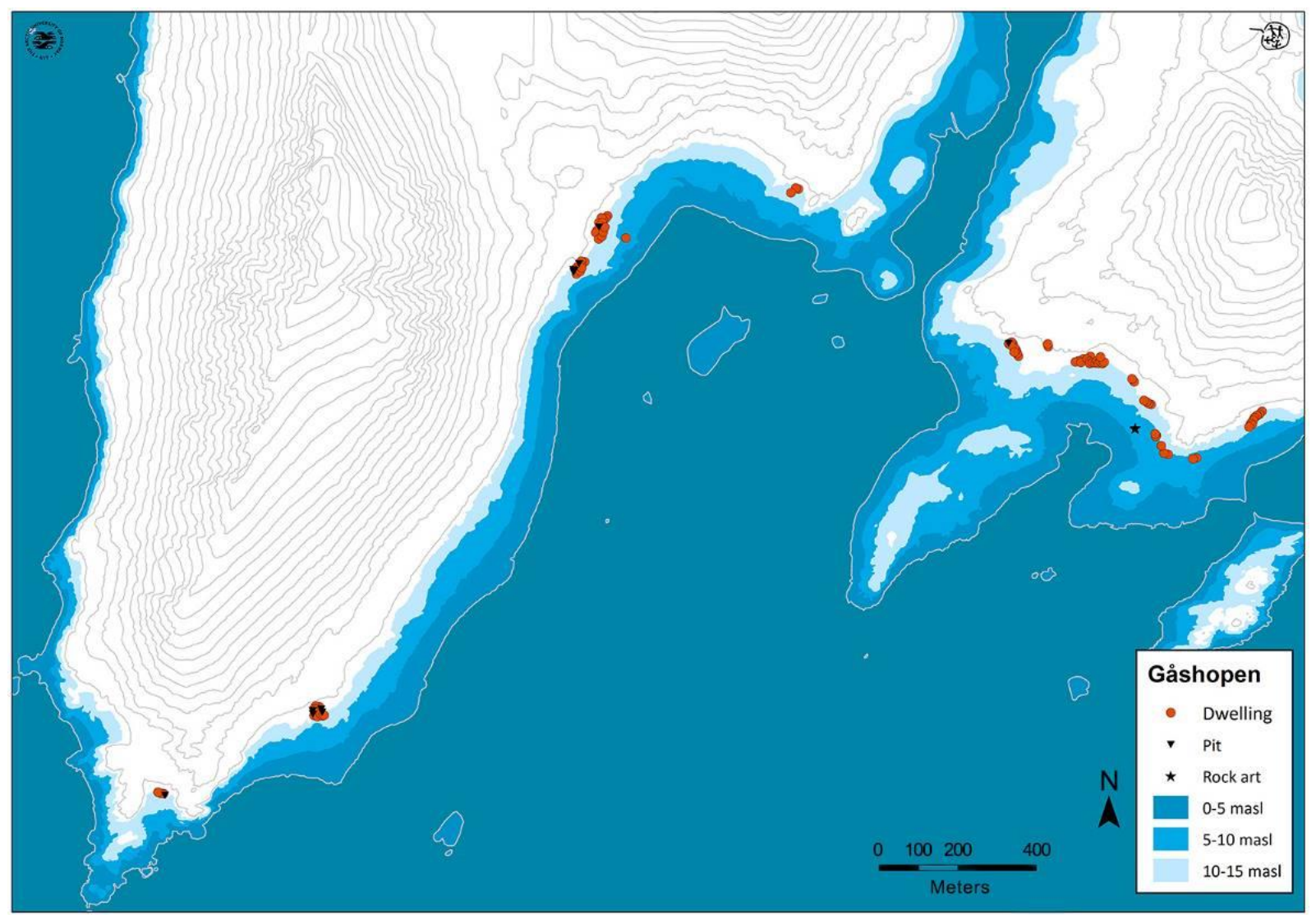

Figure 3 - Spatial distribution of sites at Gåshopen on Sørøya with reconstructed shorelines at 5, 10 and 15 masl (map by M.S. Lundgren, UiT) 


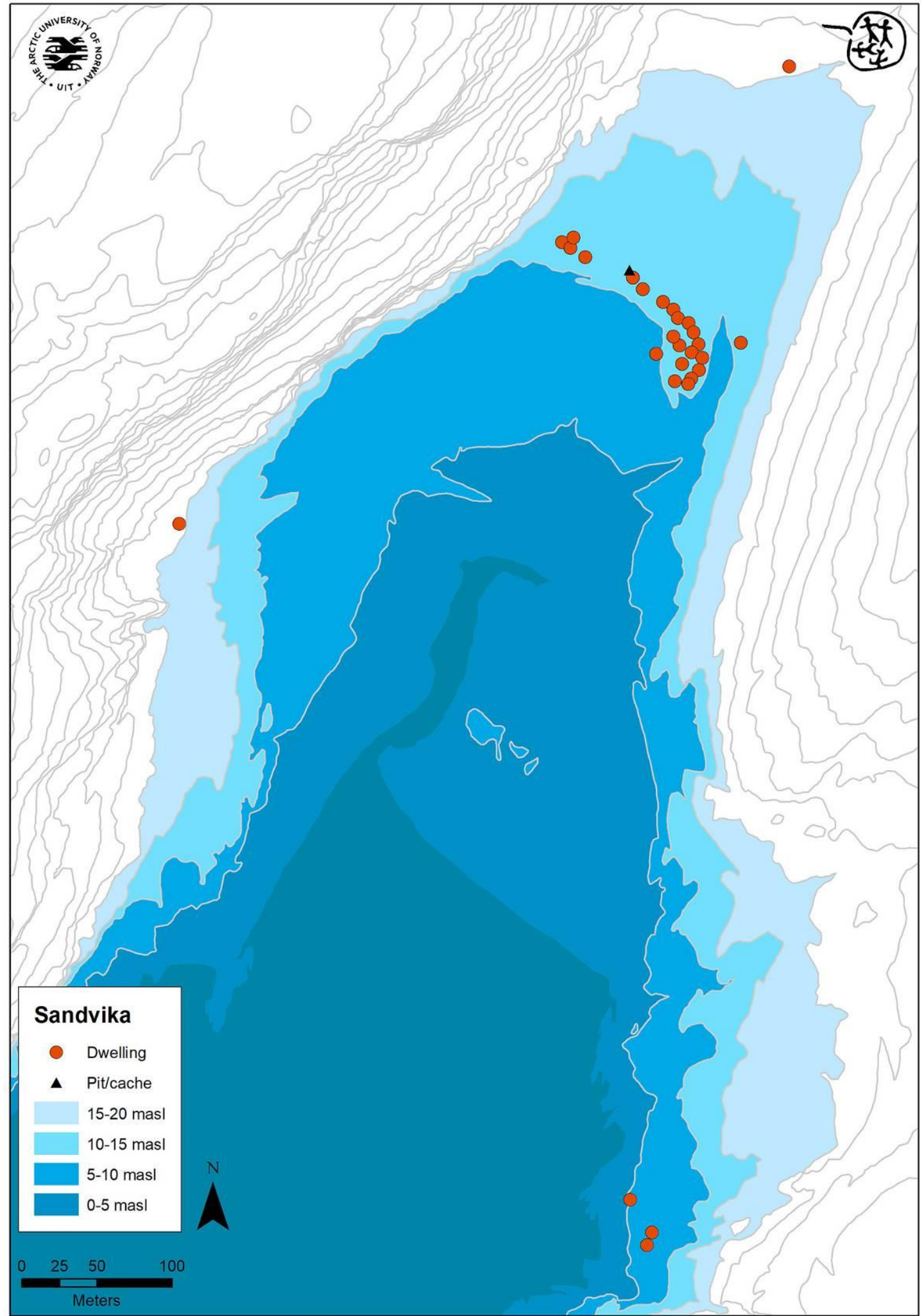

Figure 4 - GIS-based map of dwellings on different heights above sea level in Sandvika, Sørøya, Norway, shown with $5 \mathrm{~m}$ elevations (map by S.G. Therkelsen, UiT)

Similarly, systematically mapping sites in a larger region, such as western Finnmark, allow us to see that some areas attracted occupation continuously throughout the Stone Age. In such areas, we see numerous sites, each with a medium to high number of dwellings (fig. 3 ).

Within a site the dwellings are often organized either in rows along beach ridges or in clusters. For example at Sandvika (fig. 4) a row of dwellings are situated on top of a marked beach ridge. Two individual dwellings are placed away from these to the west and north. They lie at higher elevations and are thus likely to be earlier than the rest of the structures. They may alternatively be associated with distinct purposes or practices, such as better outlook, separation of some individuals from the rest of the residential group, etc. There is also a dense cluster of house-pits in an area just below the dwellings along the top of the beach ridge. Based on their placement and formal features, the dwellings on the ridge are likely earlier than those in the lower cluster. Three dwellings south of the rest are placed at the lowest elevation and 
must be the latest, inhabited after the main settlement area was abandoned, probably because it had become too distant from the shore. Direct access to safe boat landing has been the main quality of a dwelling site in this region, as demonstrated by the systematic documentation of site preferences. Detailed mapping aids discussion on the internal organization of the sites.

\section{Documenting dwelling structures}

Systematic recording of dwelling characteristics can provide valuable insights into construction principles, but perhaps more importantly on chronology, group size, social structuring of dwelling use, habitation duration and intensity.

Above ground, dwellings may look circular, oval, square or rectangular (fig. 5). However, excavations have revealed that the large majority originally had angled corners. This suggests that some kind of wooden frame supported the wall-banks. Excavated material from the construction and waste material from the occupation deposited around the floor area may be visible as low banks along the sides. A forthcoming study of all known inland house-pits in northernmost Norway by H.P. Blankholm and M. Skandfer concludes that information of overall shape is the least distinct characteristic relative to size, chronology and regional variations. Reports seldom state if shape is determined based on an impression of the inner floor area or on the outer delimitation towards the natural terrain. Mostly it seems that 'shape' is decided based on normative evaluation of the structure by individual archaeologists, more than its actual geometrical shape. Our experience from systematic recording of several hundred dwellings in coastal western Finnmark is also that how we experience overall shape is not neces- sarily supported by the measurements. This speaks against using shape as main category to describe and compare dwellings between sites and over regions.

How well the original shape has been preserved must largely be attributed to the quality of the subsoil and taphonomic processes. However, overall shapes observed at a given site may deliver general information on the relative appearance of each dwelling, and differences between structures may provide indications of actual variation in construction principles and perhaps in use. Mapping the delimitation of structures enable us to produce maps that provide valuable visualizations of variation, but also of clustering and super-imposing structures (fig. 5).

Measured sizes contribute substantially to our knowledge of in- and between-site variability in dwellings and can be used to investigate time-space patterns. Our experience is that length and width have regularly been measured, but with a high degree of individual practices. Again, survey reports do not systematically inform if the measures include only inner floor or also visible walls, and seldom state what kind of measure-tool was used. Inner and outer measures provide different information. Individual assessment of where to define the transition between floor and wall may influence the result, but taking taphonomic processes critically into account, inner measures still provide the most comparable sizes of dwelling areas. In our material inner width varies considerably less than length. Width lies around $3 \mathrm{~m} \pm 0,5$ and length varies between c. 2,5 and 4,5 m. We seldom find dwellings longer than $5 \mathrm{~m}$ in our study region, but despite this, dwellings clearly exhibit different length: width ratios and sizes differ within sites.

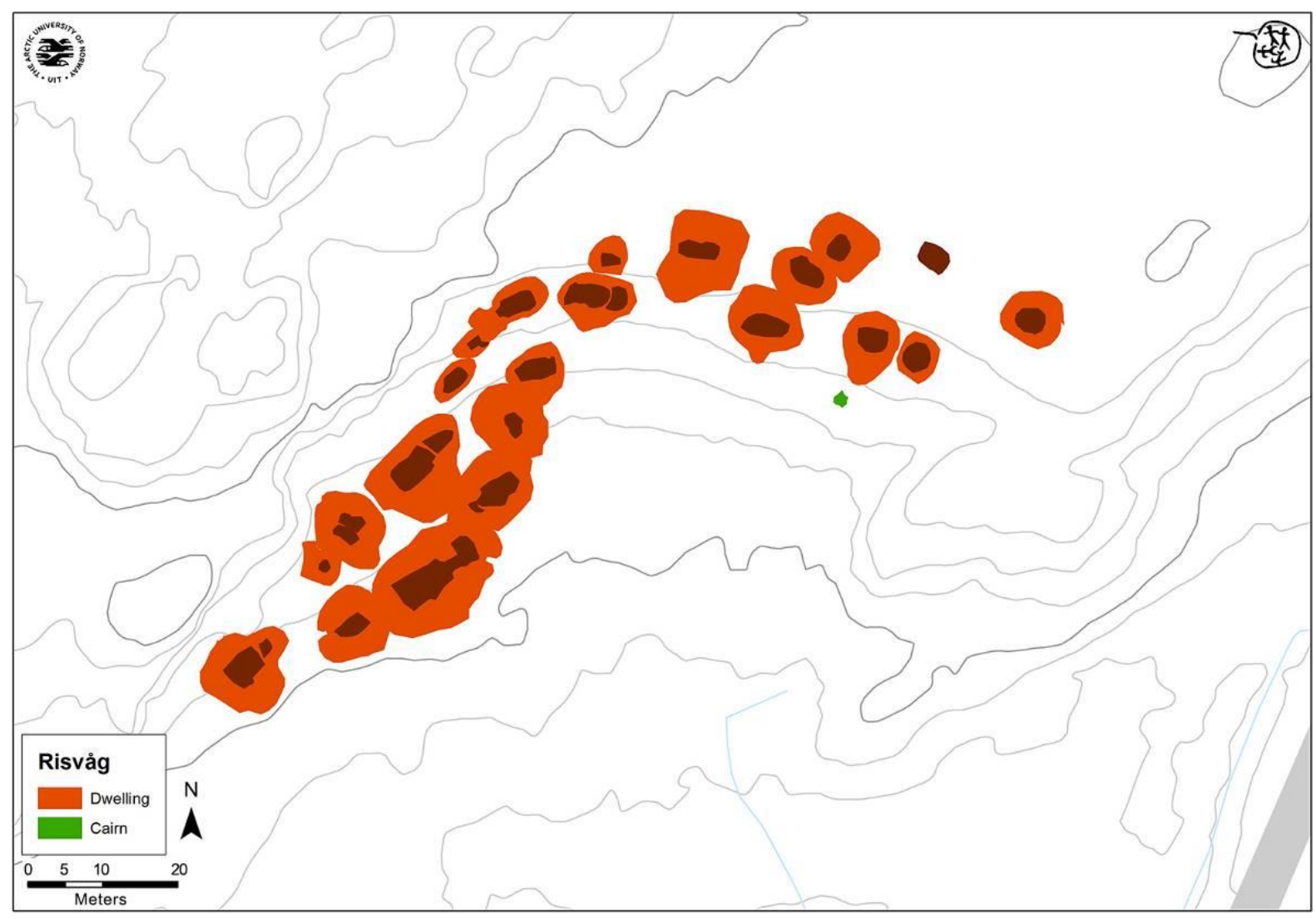

Figure 5 - Detailed map of dwelling structures in Risvåg, Sørøya, Norway, based on CPOS measuring. Shown with $1 \mathrm{~m}$ elevations (map by S.G. Therkelsen, UiT) 
Although tent-rings from lighter dwelling structures exist, it seems that a lowered floor with walls around is an important part of the prevailing construction principle of Stone Age dwellings in northernmost coastal Norway. The depth of a dwelling depression, typically between 0,2 and $0,7 \mathrm{~m}$, indicates the amount of effort investigated in the construction, and indirectly inform of settlement duration or season; one would expect that more time was invested in a solid structure supposed to be used over a long period, alternatively repeatedly, particularly in the cold season. One could also speculate that repeated use could have included several extensive cleanings of the floor, resulting in gradually deeper floor level. Excavations, however, regularly provide stratigraphically ordered dates from separate time-frames. This suggests the latter was not the case. When visiting known sites we experience that depth is not systematically measured in older survey reports, and that instead a normative evaluation of depth or shallowness is given. If measured, it is not stated if the measure is taken from floor level to top of wall (and wall heights can vary considerably around the same structure) or to top of natural level outside the structure (which can also vary considerably between front and back in sloping terrain). We chose to measure with a CPOS height above sea level in the middle of the floor area and on top of natural ground midway along one of the sidewalls. In flat terrain, the measure-point outside the structure will be of less concern, but in sloping terrain, it will provide a comparable mean-value of depth. Our results show that dwellings in coastal western Finnmark are very rarely dug deeper than $0,5 \mathrm{~m}$ into the natural surface.

Size measures give comparable information of different dwellings within and between sites and across chronological phases. Optimally, length, width, depth and orientation should be measured systematically, and methodological considerations and tools used should explicitly be accounted for. This will make it possible to critically evaluate and discuss results, also against excavated dwellings.

A number of other elements related to the main structure have been reported, such as pits, heaps/middens, apexes, openings or smaller depressions in the walls, varying floor levels, boiling-stone concentrations and possible hearth areas. Many of these can only be observed in areas with very little vegetation, and excavations have revealed that some of the above-ground observations are only results of taphonomic processes or natural differences in plant cover. Particular construction details are time-consuming to document, it is impossible to do systematic recording, and one must recognize a degree of uncertainty. Although impossible to systematically record and compare between dwellings, observations of particular details can add to observed withinand between-site variation or similarities without digging into the structures. We have - although far from systematically - recorded a number of elements that can be indicative of variation and complexity in construction principles. Among this variation is inclusion of natural features, such as boulders and cliff walls, into the dwelling structures.

\section{Discussion: patterns and variability}

During our surveys, we have recorded a substantial number of new sites and increased the number of dwellings in the region with roughly $30 \%$. This high proportion of new dwellings is much the same in all parts of western Finnmark from Altafjord to Sørøya. Our documentation has resulted in a much more detailed understanding of the variations in the coastal landscape of western Finnmark and the Stone Age settlement patterns.

The typical Stone Age dwelling in northernmost Norway is a pit-house, where the floor area has been dug out in order to achieve a lowered interior space compared to the natural terrain. Dwelling structures of various shapes and sizes are in northern Norway known from c. $9500 \mathrm{BC}$, and pit-houses from around $8000 \mathrm{BC}$ onwards $[2 ; 1]$. Povl Simonsen [3; 4] originally established four types of prehistoric semi-subterranean houses on the basis of his comprehensive excavations in Varanger, eastern Finnmark. The main types were the small, oval or circular 'Karlebotn house' of $15-20 \mathrm{~m}^{2}$, after excavation, and the larger rectangular 'Gressbakken house', often described as deep, and with a 30$50 \mathrm{~m}^{2}$ floor area after excavation. Later, the types were established as generic for a much wider region. The older 'Karlebotn house' has been dated to c. 3700-3000 BC and the 'Gressbakken house' to c. 2200-1800 BC [5]. Since Simonsen, formal, temporal and regional variation in house-pit structures has, with a few exceptions, gained little attention in publications, even though it is becoming increasingly clear that neither the division of most pit-houses into two categories, nor the narrow timeframes, hold up to scrutiny.

When construction details are omitted from descriptions of dwelling structures, variation is under-communicated and an impression of separable 'types' is upheld. Recent large-scale rescue excavation projects, soilstripping extensive areas, have documented overlapping structures, structural adaptations to local topography, and radiocarbon dates indicating several occupation phases. Based on the large excavated and surveyed material from our study area, we find than dwellings on the same site and elevation often exhibit considerable variation. Incorporation of natural elements, such as cliff walls and large boulders into the structure suggests that location and not only formal characteristics was important for how a dwelling was constructed; while certain qualities for a dwelling were sought, structures were adjusted to fit the site topography. As has been observed for inland housepits in northern Norway, shapes and sizes seem not to group in distinctive and clearly separable 'types' in relation to chronology. At the coast, considerable yet discrete formal variation is paired with reuse of the same dwelling plots over centuries and decades [1]. These findings urge for more detailed documentation in order to consider variation, and to question the relevance of generic dwelling types.

Variation in dwelling size and construction principles may be related to functional variation on different levels, such as different types of activities or different numbers of residents in each house. Differences may be linked to seasonal variations. The number of dwellings at a site and the local topography may indicate the role of a site within the settlement organization. Sites such as Sandvika, with many dwellings spread across different heights above sea level, good landing, shelter, fresh water and closeness to a variety of resources, are likely to have served as residential bases in many different chronological periods. Sites with fewer dwellings and sites placed on exposed points are more likely to be short term sites, used when on the look-out for and exploiting specific resources. 
Coastal western Finnmark exhibits variation, where in some areas sites are situated in small enclaves between major obstacles of steep coastlines and ocean cliffs, while in other it would be possible to walk between the sites along the shoreline for several kilometres. Clustering of sites and dwellings in some local areas indicate that these were more attractive than others. In this landscape - or rather seascape - sea-worthy boats were a prerequisite. The preferences for site locations and travels must therefore partly be evaluated from a boat navigating perspective. As a consequence, boat landing qualities were the crucial aspect in settlement site location.
The reconstruction of the past landscape with higher sea levels in combination with knowledge of where and in which seasons specific resources may be found form the basis for examining the economic diversity found amongst the hunter-fisher-gatherers in western Finnmark. The archaeological record here bears clear evidence of a strong maritime orientation. However, we must be open to the idea that also in a coastal landscape, with emphasis on marine resources, different settlement and mobility strategies may be chosen and the landscape inhabited and exploited in different ways.
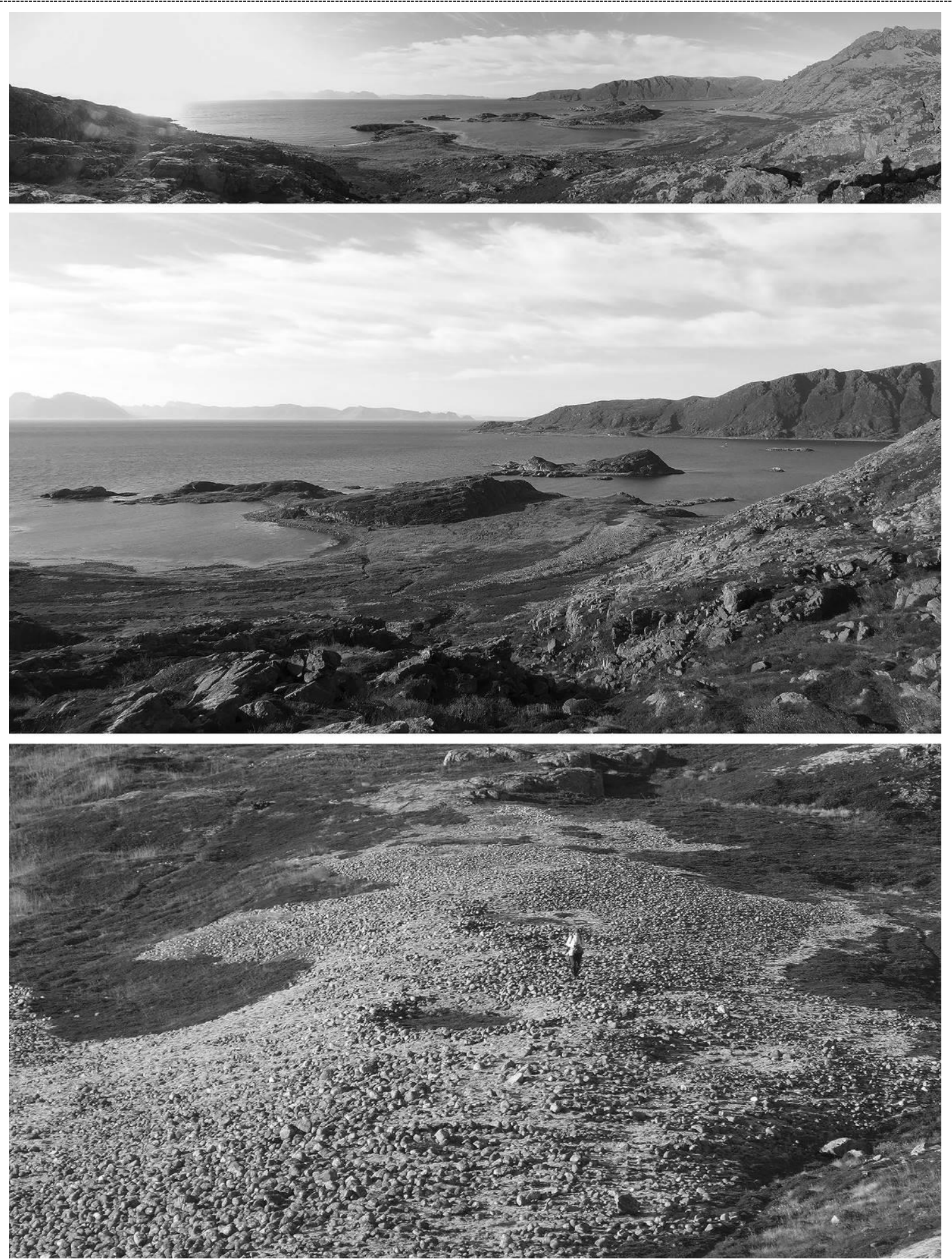

Figure 6 - Three levels of dwelling documentation at Taborshamn, Sørøya, Norway. From the wider seascape, via the site area, to the single house structures (photos and collage by J.M. Gjerde, NIKU) 


\section{Conclusion}

Systematic and detailed documentation of dwellings, sites and environment with explicit mention of parameters and tools employed is crucial, if the ambition is to analyze data-sets for temporal and spatial patterns and variation at all three levels. This is perhaps particularly important for the dwelling structures, as former typological categories have been used widely and uncritically. As a result of this there has been limited discussion of actual variation in size, construction and function within temporal and spatial frames. More extensive analyses of the material are required in order to incorporate the information in discussions of variations in dwelling and site diversity within a wider and varied landscape.

\section{References:}

1. Damm C., Skandfer M., Jørgensen E.K., Sjøgren P., Vollan K.W.B., Jordan P. Investigating long-term human ecodynamics in the European Arctic: towards an integrated multi-scalar analysis of early and mid Holocene cultural, environmental and palaeodemographic sequences in Finn- mark County, Northern Norway // Quarternary International. 2019. Vol. 549. P. 52-64.

2. Gjerde J.M., Skandfer M. Mesolithic houses in Arctic Norway: a case study from Tønsnes, Tromsø // The Early Economy and Settlement in Northern Europe. Pioneering, resource use, coping with change / H.P. Blankholm (ed.). Sheffield: Equinox Publishing Ltd, 2018. P. 59-76.

3. Simonsen P. Varanger-funnene II. Fund og udgravninger på fjordens sydkyst // Tromsø Museums Skrifter. Vol. VII (2). Tromsø, 1961. 524 p.

4. Veidemenn på Nordkalotten. Hefte 3. Yngre steinalder og overgang til tidlig metalltid. Stensilserie B. Tromsø: Universitetet of Tromsø, 1979.

5. Olsen B. Bosetning og samfunn i Finnmarks forhistorie. Oslo: Universitetsforlaget, 1994. 158 p.

The surveys are part of the ongoing «Stone Age Demographics: multi-scale exploration of population variations and dynamics" project, funded by the Research Council of Norway (project number 261760). The Norwegian nature surveillance has provided valuable practical assistance.

\begin{tabular}{|c|c|}
\hline Information about the author(-s): & Информация об авторе(-ах): \\
\hline $\begin{array}{l}\text { Skandfer Marianne, PhD, professor at The Arctic } \\
\text { University Museum of Norway; The Arctic University } \\
\text { of Norway (Tromso, Kingdom of Norway). } \\
\text { E-mail: marianne.skandfer@uit.no. }\end{array}$ & $\begin{array}{l}\text { Скандфер Марианна, PhD, профессор музея; } \\
\text { Арктический университет Норвегии (г. Тромсё, } \\
\text { Королевство Норвегия). } \\
\text { E-mail: marianne.skandfer@uit.no. }\end{array}$ \\
\hline $\begin{array}{l}\text { Damm Charlotte, PhD, professor at the Department } \\
\text { of Archaeology, History, Religious Studies and Theology; } \\
\text { The Arctic University of Norway (Tromso, Kingdom } \\
\text { of Norway). E-mail: charlotte.damm@uit.no. }\end{array}$ & $\begin{array}{l}\text { Дамм Шарлотта, PhD, профессор кафедры } \\
\text { археологии, истории, религиоведения и теологии; } \\
\text { Арктический университет Норвегии (г. Тромсё, } \\
\text { Королевство Норвегия). } \\
\text { E-mail: charlotte.damm@uit.no. }\end{array}$ \\
\hline $\begin{array}{l}\text { Gjerde Jan Magne, PhD, research at the High North } \\
\text { Office; Norwegian Institute for Cultural Heritage } \\
\text { Research (Tromso, Kingdom of Norway). } \\
\text { E-mail: jan.magne.gjerde@niku.no. }\end{array}$ & $\begin{array}{l}\text { Йёрде Ян Мarнe, PhD, научный сотрудник отдела } \\
\text { крайнего севера; Норвежский институт по изучению } \\
\text { культурного наследия (г. Тромсё, Королевство } \\
\text { Норвегия). E-mail: jan.magne.gjerde@niku.no. }\end{array}$ \\
\hline
\end{tabular}

\section{Для цитирования:}

Skandfer M., Damm Ch., Gjerde J.M. Stone Age dwellings, sites and environment in coastal northern Norway: surveys and documentation of house-pit sites // Samara Journal of Science. 2021. Vol. 10, iss. 3. P. 153-161. DOI: 10.17816/snv2021103204. 